\title{
Processing Effects on Physicochemical Properties of Creams Formulated with Modified Milk Fat
}

\author{
J. C. Bolling, ${ }^{1}$ S. E. Duncan, ${ }^{2}$ W. N. Eigel, ${ }^{2}$ and K. M. Waterman ${ }^{2}$ \\ ${ }^{1}$ Bolling Steel Co., 5933 German Rd., Salem, VA 24153 \\ ${ }^{2}$ Department of Food Science and Technology, \\ Virginia Polytechnic Institute and State University, \\ Blacksburg 24061
}

\begin{abstract}
Type of thermal process [high temperature, short time pasteurization (HTST) or ultra-high temperature pasteurization (UHT)] and homogenization sequence (before or after pasteurization) were examined for influence on the physicochemical properties of natural cream (20\% milk fat) and creams formulated with $20 \%$ low-melt, fractionated butteroil emulsified with skim milk, or buttermilk and butter-derived aqueous phase. Homogenization sequence influenced physicochemical makeup of the creams. Creams homogenized before pasteurization contained more milk fat surface material, higher phospholipid levels, and less protein at the milk fat interface than creams homogenized after pasteurization. Phosphodiesterase I activity was higher (relative to protein on lipid globule surface) when cream was homogenized before pasteurization. Creams formulated with skim milk and modified milk fat had relatively more phospholipid adsorbed at the milk fat interface. Ultra-high-temperature-pasteurized natural and reformulated creams were higher in viscosity at all shear rates investigated compared with HTST-pasteurized creams. High-temperature, short time-pasteurized natural cream was more viscous than HTST-pasteurized reformulated creams at most shear rates investigated. High-temperature, short time-pasteurized creams had better emulsion stability than UHT-pasteurized creams. Cream formulated with buttermilk had creaming stability most comparable to natural cream, and cream formulated with skim milk and modified butteroil was least stable to creaming. Most creams feathered in a $\mathrm{pH}$ range of 5.00 to 5.20 , indicating that they were moderately stable to slightly unstable emulsions. All processing sequences yielded creams within sensory specifications with the exception of treatments homogenized before UHT pasteurization and skim milk formulations homogenized after UHT pasteurization.
\end{abstract}

Received July 5, 2004.

Accepted December 2, 2004

Corresponding author: Susan E. Duncan; e-mail: duncans@vt.edu.
(Key words: reformulated cream, modified milk fat, processing, physicochemical property)

Abbreviation key: MFGM = milk fat globule membrane, pMFGM = processed milk fat globule membrane.

\section{INTRODUCTION}

Before processing, interactions between milk proteins and milk fat are limited. Milk fat is contained within the milk fat globule membrane (MFGM), and the casein and whey proteins are found predominantly in the serum phase of the milk. Processes such as heating, cooling, and homogenization can significantly alter serum protein, micellar protein, and composition of material at the fat globule surface, resulting in vastly different composition at the milk fat-serum interface compared with native MFGM. These structural changes can greatly influence physical properties of the milk system such as viscosity and creaming stability (Dalgleish and Sharma, 1993; Corredig and Dalgleish, 1997).

Levels of incorporation of $\beta$-lactoglobulin and $\kappa$-casein into the processed milk fat globule membrane (PMFGM) have been found to be dependent on the extent of heat treatment (Corredig and Dalgleish, 1998; Lee and Sherbon, 2002). Iametti et al. (1997) found incorporation of milk proteins (particularly $\beta$-lactoglobulin) into the pMFGM of homogenized cream (32\% milk fat) to be lower than reported for whole or reconstituted milk, possibly due to the higher ratio of fat to protein in cream. Segall and Goff (2002) produced emulsions of butteroil (25\%) and whey proteins that exhibited substantial coalescence when whipped. However, when skim milk powder/water solutions were added to the butteroil/whey emulsions, protein bound at the fat surface increased and fat coalescence decreased upon whipping.

Method of processing vastly influences the composition of the pMFGM. If homogenization occurs after heat treatment, the serum proteins, having been denatured before homogenization, will already be complexed with 
casein micelles and will not be able to undergo any further reactions (Dalgleish and Sharma, 1993). In contrast, when milk is homogenized before heat treatment, casein proteins cover the newly formed milk fat surface, and no whey proteins are present on the milk fat surface (Walstra and Oortwijn, 1982). Subsequent heating of this milk causes serum proteins and the adsorbed casein to complex on the increased milk fat surface area. Iametti and coworkers (1997) found that pasteurization alone induced only minor changes in the surface properties of the fat globules of $32 \%$ milk fat cream. Smith et al. (2000) found that UHT-pasteurized whipping cream was less stable than HTST-pasteurized whipping cream due to faster deterioration of the protein network in the serum phase.

Milk fat can be fractionated, using methods such as the Tirtiaux process or supercritical fluid extraction, to alter nutritional and functional attributes compared with natural milk fat. These processes involve isolation of butteroil before fractionation, thereby requiring emulsification for incorporation into many food systems. Emulsification can be accomplished by combining modified milk fat with surface-active agents into reformulated dairy products such as creams. Milk-derived components, such as skim milk, sweet buttermilk, butter-derived aqueous phase, whey proteins, casein dispersions, and purified MFGM suspensions have proven to successfully emulsify butteroil. Skim milk is an abundant source of whey and casein proteins whereas sweet buttermilk and butter-derived aqueous phase are abundant in phospholipids from MFGM fractions (Elling et al., 1996; Scott et al., 2003a).

Elling et al. (1996) found that pMFGM composition of reformulated creams containing skim milk or buttermilk and cholesterol-stripped butteroil resembled the components used to emulsify them, with protein being the primary emulsifier. Cream formulated with buttermilk contained more phospholipid than creams formulated with skim milk, indicating the presence of more native MFGM. Natural and reformulated creams homogenized at higher pressures contained more surface material at the membrane interface than corresponding creams homogenized at lower pressures (13.6/3.4 MPa vs. 10.2/3.4 MPa). Scott et al. (2003a) investigated the effect of cream separation temperature on composition of components (skim milk or buttermilk and butterderived aqueous phase) used in reformulated creams and on the resulting pMFGM. No significant differences in composition of pMFGM were attributed to separation temperature.

This research examined the effect of HTST pasteurization, UHT pasteurization, and homogenization sequence (pasteurization before or after homogenization) on the chemical and physical properties of natural creams and creams formulated with a low-melting range butteroil emulsified with skim milk, or buttermilk and butter-derived aqueous phase.

\section{MATERIALS AND METHODS}

\section{Separation of Cream and Skim}

Raw milk obtained from the Virginia Tech dairy farm was separated $\left(55^{\circ} \mathrm{C}\right)$ into 30 to $35 \%$ milk fat cream and skim milk using a pilot plant separator (Elecrem, model 1G, 6400 rpm, Bonanza Industries, Inc., Calgary, Alberta, Canada). Skim milk obtained from separation was subsequently used for formulation of experimental creams. Within $1 \mathrm{~h}$, cream obtained from separation was standardized to 30 to $35 \%$ milk fat and vat-pasteurized at $68.3^{\circ} \mathrm{C}$ for $30 \mathrm{~min}$. After cooling $\left(21.5^{\circ} \mathrm{C}\right)$, cream was either tempered $\left(13^{\circ} \mathrm{C}\right)$ for $14 \mathrm{~h}$ for subsequent churning or stored $\left(4^{\circ} \mathrm{C}\right)$ for further processing. The skim milk portion was not heat-treated and was stored at $4^{\circ} \mathrm{C}$ until experimental cream formulation.

\section{Preparation of Buttermilk and Butter-Derived Aqueous Phase}

Buttermilk was obtained using the methods of Elling et al. (1996). Tempered cream $\left(13^{\circ} \mathrm{C}\right)$ was mechanically churned (Gem Dandy Standard Electric Churn, Bonanza Industries, Inc.) to produce buttermilk and butter. Buttermilk was separated from butter by pouring through cheesecloth and pressing excess buttermilk from butter granules. The resulting buttermilk was stored at $4^{\circ} \mathrm{C}$ until further processing and usage as a component for formulation of experimental creams.

Butter-derived aqueous phase was received from a commercial processor (Grasslands Dairy Products, Inc., Greenwood, WI) for use as a formulation component. Commercially produced butter-derived aqueous phase was obtained from $38.5 \%$ milk fat cream pasteurized at $85.6^{\circ} \mathrm{C}$. After pasteurization, the cream was cooled to $6.1^{\circ} \mathrm{C}$ in a plate heat exchanger. The cream then went through a 2-stage commercial separation process, was tempered at $10.6^{\circ} \mathrm{C}$ for 8 to $10 \mathrm{~h}$, and the butter was obtained by churning. Serum or aqueous phase was recovered from butter.

\section{Characterization of Low-Melt Fractionated Butteroil}

Low-melt fractionated butteroil was obtained from anhydrous milk fat utilizing the Tirtiaux fractionation procedure at the Wisconsin Center for Dairy Research (University of Wisconsin, Madison). The dropping point was $18^{\circ} \mathrm{C}$, and at a temperature of $25^{\circ} \mathrm{C}$, percentage solid fat was zero. The low-melt fractionated butteroil 
Table 1. Description and experimental treatments of natural and reformulated creams containing $20 \%$ milk fat.

\begin{tabular}{lll}
\hline Cream formulation & $\begin{array}{l}\text { Homogenization } \\
\text { sequence }\end{array}$ & \begin{tabular}{l} 
Pasteurization $_{\text {type }^{2}}$ \\
\hline Natural cream
\end{tabular} \\
Natural cream & Before & HTST \\
Natural cream & After & HTST \\
Natural cream & Before & UHT \\
$80 \%$ Skim milk $+20 \%$ lmbo & After & UHT \\
$80 \%$ Skim milk $+20 \%$ lmbo & Before & HTST \\
$80 \%$ Skim milk $+20 \%$ lmbo & After & HTST \\
$80 \%$ Skim milk $+20 \%$ lmbo & Before & UHT \\
$70 \%$ Buttermilk $+20 \%$ lmbo $+10 \%$ AP & After & UHT \\
$70 \%$ Buttermilk $+20 \%$ lmbo $+10 \%$ AP & Before & HTST \\
$70 \%$ Buttermilk $+20 \%$ lmbo $+10 \%$ AP & After & HTST \\
$70 \%$ Buttermilk $+20 \%$ lmbo $+10 \%$ AP & Before & UHT \\
\hline
\end{tabular}

\footnotetext{
${ }^{1}$ Two-stage homogenization performed before or after pasteurization. First stage $=13.6 \mathrm{MPa}$, second stage $=3.4 \mathrm{MPa}$.

${ }^{2} \mathrm{HTST}=77^{\circ} \mathrm{C}, 15 \mathrm{~s} ; \mathrm{UHT}=148^{\circ} \mathrm{C}, 2 \mathrm{~s}$

${ }^{3} \mathrm{lmbo}=$ Low-melt butteroil $\left(0 \%\right.$ solid fat at $25^{\circ} \mathrm{C}$; dropping point $\left.18^{\circ} \mathrm{C}\right)$.

${ }^{4} \mathrm{AP}=$ Butter-derived aqueous phase. Commercially obtained from Grassland Dairy Products, Inc., Greenwood, WI.
}

had medium-yellow coloration and butter-like flavor (Kaylegian, 1998).

\section{Cream Reformulation}

Low-melt fractionated butteroil (20\%) was melted (45 to $\left.50^{\circ} \mathrm{C}\right)$ and combined with skim milk $(80 \%)$ or buttermilk $(70 \%)$ and butter-derived aqueous phase (10\%) into 2 experimental formulations containing $20 \%$ milk fat. Natural cream was standardized with skim milk to contain $20 \%$ milk fat and used as a reference formulation. Aliquots of each cream formulation were subjected to 4 processing sequences (Table 1 ).

High temperature, short time pasteurization, and UHT pasteurization were accomplished using a tubular laboratory pasteurization system (Microthermics UHT/ HTST Laboratory 25-HV, Microthermics, Inc., Raleigh, NC). Two-stage homogenization at a pressure of 13.6 $\mathrm{MPa}$ (first stage) followed by 3.4 $\mathrm{MPa}$ (second stage) was accomplished using a laboratory homogenizer (model 15MR, APV Gaulin, Inc., Everett, MA).

Samples $(3.78 \mathrm{~L})$ of each cream formulation were HTST-pasteurized $\left(77^{\circ} \mathrm{C}, 15 \mathrm{~s}\right)$ before homogenization. Formulations were warmed $\left(27.7^{\circ} \mathrm{C}\right)$ and stirred using a hand mixer before pasteurization. Cream exited the outlet valve of the pasteurizer at a temperature of $55^{\circ} \mathrm{C}$. Creams were then homogenized, cooled in an ice bath, and stored at $4^{\circ} \mathrm{C}$.

High temperature, short time pasteurization was carried out after homogenization on samples $(3.78 \mathrm{~L})$ of each cream formulation. Formulations were warmed $\left(55^{\circ} \mathrm{C}\right)$ and stirred with a hand mixer to ensure uniformity, homogenized, cooled $\left(27.7^{\circ} \mathrm{C}\right)$, and HTST-pasteur- ized. Homogenized and pasteurized creams were stored at $4^{\circ} \mathrm{C}$.

After all treatments receiving HTST pasteurization were completed, the pasteurizer was reconfigured for UHT pasteurization parameters $\left(148^{\circ} \mathrm{C}, 2 \mathrm{~s}\right)$ and the homogenizer was cleaned and sanitized. Aliquots of each cream formulation were: 1) homogenized (as described above) followed by UHT pasteurization $\left(148^{\circ} \mathrm{C}\right.$ for $2 \mathrm{~s}$ ), or 2) UHT pasteurized (cream exited the outlet valve at a temperature of $55^{\circ} \mathrm{C}$ ) followed by homogenization.

\section{Fat, Protein, and Phospholipid Determination of Creams and Membrane Material}

Protein content was determined with a dye-binding assay (DC BioRad assay, BioRad Laboratories, Hercules, CA). The Babcock procedure (Marshall, 1993) was used to measure fat content of cream formulations. Total lipid content of cream treatments was determined using the methods of Folch et al. (1957). Determination of phospholipid content required lipid extraction using the methods of Folch et al. (1957). Phospholipids in the lipid extracts were separated using a silicic acid column as described by Rouser et al. (1966). A quantitative analysis of the amount of phosphorous in the phospholipid extract was made using a spectrophotometric method (Rouser et al., 1966). The value obtained from the analysis was multiplied by a factor of 25 to convert phosphorous content to phospholipid content (Anderson et al., 1977). 


\section{Analysis of Milk Fat Surface Material}

The amount of phospholipid and protein adsorbed on the surface of the milk fat globule was determined as described by Elling et al. (1996). Creams were centrifuged $\left(60 \mathrm{~min} ; 2^{\circ} \mathrm{C} ; 175,000 \times g\right)$ in a Beckman L2-65B Ultracentrifuge (Beckman Instruments Inc., Palo Alto, CA). Centrifugation separated each cream into a lipidrich cream plug and a skim phase. The cream plug containing lipid-associated membrane material, including lipid complexed with protein, was collected. Two cycles of slow freezing and thawing of the cream plug followed by centrifugation $\left(60 \mathrm{~min}, 2^{\circ} \mathrm{C}, 25,000 \mathrm{rpm}\right)$ in a Beckman L2-65B ultracentrifuge allowed release of components of the milk fat surface material from the milk fat. The pellet containing milk fat surface material was obtained and lyophilized in a freeze drier (Freezemobile 12 SL, Virtis Co., Inc., Gardiner, NY) with drying chamber (10-MR-SM Vacuum Stoppering and Manifold Drying Chamber, Virtis Co., Inc.). Pellets were ground into powder with a mortar and pestle. Lipid extraction of the pellet then was carried out using the methods of Bligh and Dyer (1959). Protein and phospholipids were analyzed as previously described. Phosphodiesterase I activity was determined as described by Brown et al. (1976).

\section{Creaming Stability}

Emulsion stability of all cream formulations was analyzed over 2 wk of refrigerated storage (Elling and Duncan, 1996). No preservatives were added. Cream was placed in 100-mL graduated cylinders, capped, and stored at $4^{\circ} \mathrm{C}$ on day of processing (d 0 ). Initial fat content on d 0 of storage was determined, and $9 \mathrm{~mL}$ from the top and $9 \mathrm{~mL}$ from the bottom of each cream treatment was evaluated for fat content using the Babcock procedure for cream (Marshall, 1993) on d 1, 3, 5, $7,9,11$, and 13 of storage. The following equation was used to determine the changes occurring in fat percentage of each layer compared with the initial fat content:

Change in fat percentage $=$

[(fat content of top or bottom layer)/

(initial fat content) $\times 100)-100]$

\section{Viscosity}

On day of formulation (d 0), 15-mL samples of each cream formulation were placed in glass tubes and stored $\left(4^{\circ} \mathrm{C}\right)$. Viscosity measurements were made on $\mathrm{d}$ 1, 7, and 13 using a Haake Rotovisco RV-12 viscometer equipped with a Haake NV spindle cup (Haake-Buchler Instruments, Paramus, NJ; Elling and Duncan, 1996; Scott et al., 2003b). A Haake A82 cooling unit main- tained a constant temperature of $7^{\circ} \mathrm{C}$ at which all measurements were taken. Shear stress measurements were taken at the following shear rates $\left(\mathrm{s}^{-1}\right): 173,346$, $692,1385,2770,1385,692,346,173$. Viscosity values then were obtained by dividing shear stress by the shear rate.

\section{Feathering Stability}

Feathering is a condition that is characterized by visible flocs of any size that appear after cream stands in the fluid in which it is dispersed for 2 to $3 \mathrm{~min}$. The feathering assay is a visual test that was carried out on duplicate samples in sodium acetate buffer $(0.012$ $M), \mathrm{pH}$ range from 4.70 to 5.60 at 2 temperatures $\left(4^{\circ} \mathrm{C}\right.$, $85^{\circ} \mathrm{C}$ ) on $\mathrm{d} 1,7$, and 13 of storage. The assay was performed using the methods of Anderson et al. (1977). The lowest buffer $\mathrm{pH}$ at which feathering failed to occur was recorded as the feathering score. Highly stable creams received scores of 5,4 , or $3(\mathrm{pH} 4.70,4.75$, or 4.81, respectively), whereas stable creams were given feathering scores of 2 or 1 ( $\mathrm{pH} 4.86$ or 4.92). Moderately stable creams were assigned a feathering score of $0(\mathrm{pH}$ 5.00) and slightly unstable creams were scored -1 or -2 ( $\mathrm{pH} 5.09$ or 5.20$)$. Unstable creams having feathering scores of $-3,-4$, or -5 ( $\mathrm{pH} 5.31,5.45$, or 5.60 , respectively) were considered unmarketable to consumers (Atherton and Newlander, 1977).

\section{Examination of Cream Quality via Microbiological Analyses and Sensory Evaluation}

Microbiological analyses (for enumeration of aerobic, psychrotrophic, and coliform bacteria) were conducted on d 0,6 , and 12 of storage. Aerobic Count and Coliform Count Petrifilms (3M, St. Paul, MN) were used for plating samples.

Creams were evaluated for sensory characteristics on d 1, 7, and 13 of storage. Experienced panelists $(n=$ 10) familiar with the sensory properties of cream used the In/Out method of specification to evaluate cream flavor (Munoz et al., 1992). A cream was considered "In" specification if it possessed the perceived mouthfeel thickness of a $20 \%$-milk fat natural cream and was "free of" to "slightly affected" with objectionable off-flavors (light-oxidized, rancid, cooked, flat, lacks freshness, malty, or fruity). When creams began to display moderate levels of off-flavors, they were deemed "Out" of specification. Creams were designated acceptable in quality if $60 \%$ of total responses were "In" specification.

Approximately $20 \mathrm{~mL}$ of each cream was poured into 28.35-g portion size plastic soufflé cups on the day the sensory test was to be conducted. Samples were identified with 3-digit codes and randomized for presentation 
Table 2. Composition ${ }^{1}$ (lipid, protein, phospholipid) of natural and reformulated creams homogenized before or after pasteurization (HTST, UHT).

\begin{tabular}{|c|c|c|c|c|}
\hline Cream formulation & $\begin{array}{l}\text { Homogenization } \\
\text { sequence/ } \\
\text { pasteurization } \\
\text { type }^{2}\end{array}$ & $\begin{array}{l}\text { Fat } \\
(\%)\end{array}$ & $\begin{array}{l}\text { Protein } \\
(\mathrm{mg} / \mathrm{g})\end{array}$ & $\begin{array}{l}\text { Phospholipid } \\
(\mathrm{mg} / \mathrm{g})\end{array}$ \\
\hline Natural cream & Before/HTST & 18.92 & 32.19 & 0.522 \\
\hline Natural cream & After/HTST & 20.50 & 30.38 & 0.491 \\
\hline Natural cream & Before/UHT & 19.58 & 32.80 & 0.517 \\
\hline Natural cream & After/UHT & 19.33 & 31.21 & 0.545 \\
\hline $80 \%$ Skim milk $+20 \%$ lmbo $^{3}$ & Before/HTST & 19.50 & 47.20 & 0.071 \\
\hline $80 \%$ Skim milk + 20\% lmbo & After/HTST & 20.00 & 43.23 & 0.067 \\
\hline $80 \%$ Skim milk $+20 \%$ lmbo & Before/UHT & 19.42 & 47.36 & 0.046 \\
\hline $80 \%$ Skim milk + $20 \%$ lmbo & After/UHT & 19.83 & 47.85 & 0.056 \\
\hline $70 \%$ Buttermilk $+20 \%$ lmbo $+10 \% \mathrm{AP}^{4}$ & Before/HTST & 19.75 & 46.36 & 0.668 \\
\hline $70 \%$ Buttermilk $+20 \%$ lmbo $+10 \% \mathrm{AP}$ & After/HTST & 20.58 & 43.59 & 0.755 \\
\hline $70 \%$ Buttermilk $+20 \%$ lmbo $+10 \%$ AP & Before/UHT & 20.67 & 49.31 & 0.739 \\
\hline $70 \%$ Buttermilk $+20 \%$ lmbo $+10 \%$ AP & After/UHT & 20.50 & 45.86 & 0.745 \\
\hline Standard Error & & 0.158 & 0.790 & 0.027 \\
\hline \multicolumn{5}{|l|}{${ }^{1}$ Values are means for 3 replications. } \\
\hline \multirow{2}{*}{\multicolumn{5}{|c|}{$\begin{array}{l}{ }^{2} \text { Two-stage homogenization performed before or after pasteurization. First stage }=13.6 \mathrm{MPa} \text {, second } \\
\text { stage }=3.4 \mathrm{MPa} \text { : HTST }=77^{\circ} \mathrm{C}, 15 \mathrm{~s} ; \mathrm{UHT}=148^{\circ} \mathrm{C}, 2 \mathrm{~s} \text {. }\end{array}$}} \\
\hline & & & & \\
\hline \multicolumn{5}{|c|}{${ }^{3} \operatorname{lmbo}=$ Low-melt butteroil $\left(0 \%\right.$ solid fat at $25^{\circ} \mathrm{C} ;$ dropping point $\left.18^{\circ} \mathrm{C}\right)$} \\
\hline \multicolumn{5}{|c|}{$\begin{array}{l}{ }^{4} \mathrm{AP}=\text { Butter-derived aqueous phase, commercially obtained from Grassland Dairy Products, Inc., Green } \\
\text { wood, WI. }\end{array}$} \\
\hline
\end{tabular}

to panelists. Panelists were given 12 samples (1 sample/ treatment) with sample temperature being maintained at $4 \pm 3^{\circ} \mathrm{C}$ throughout the sensory evaluation. Panelists independently sampled cream treatments in the sensory laboratory of the Department of Food Science and Technology, Virginia Tech (Blacksburg, VA) under incandescent lighting.

\section{Statistical Analyses}

This study was replicated 3 times. A split-plot design with subsampling was used. The whole-plot factor was the cream formulation. The split-plot factor was a $2 \times$ 2 factorial with factors of homogenization sequence and pasteurization type. For comparisons of effects, a procedure mixed version was used. A multivariate split-plot (repeated measures with a split-plot structure between subjects) also was used in this study. Statistical analyses were conducted using SAS (SAS Institute, 1985).

\section{RESULTS AND DISCUSSION}

\section{Composition of Natural and Reformulated Creams}

High temperature-short time, and UHT thermal processes, in sequence with homogenization of natural creams and creams reformulated with low-melt butteroil were investigated. All emulsions in this study were determined to be of oil-in-water type when examined by light microscope. Table 2 describes the fat, protein, and phospholipid composition of the cream formulations. Regardless of pasteurization process or homog- enization sequence, creams formulated with skim milk and buttermilk/aqueous phase contained similar amounts of protein whereas natural creams were lower in protein content. These results are in agreement with those of Scott et al. (2003a). However, Elling et al. (1996) reported no difference in protein content among creams formulated with low cholesterol butteroil and skim milk or buttermilk and aqueous phase. Natural cream and buttermilk/aqueous phase cream formulations had more phospholipid available for emulsification than creams formulated with skim milk. This is to be expected because skim milk contains less phospholipid than buttermilk or butter-derived aqueous phase (Scott et al., 2003a).

\section{Changes in MFGM}

Homogenization reduces mean milk fat globule diameter to $1 \mu \mathrm{m}$ or less and increases surface area of milk fat globules from 4 to 10 times (Walstra, 1975). The increased surface area of the milk fat globules cannot be covered by native MFGM, and other milk constituents (mainly proteins) must fill the gaps on the milk fat globule surface created by homogenization (Dalgleish and Banks, 1991).

Table 3 compares composition of the pMFGM for creams homogenized before and after pasteurization. Significantly more $(P<0.05)$ MFGM fragments were present in creams homogenized before pasteurization. This was demonstrated by phosphodiesterase, a marker enzyme within the native MFGM, displaying signifi- 
Table 3. Processed milk fat globule membrane (MFGM) composition ${ }^{1}$ of natural and reformulated cream homogenized before and after pasteurization.

\begin{tabular}{|c|c|c|c|}
\hline \multirow[b]{2}{*}{ Variable } & \multicolumn{2}{|c|}{ Homogenization sequence $^{2}$} & \multirow{2}{*}{$\begin{array}{l}\text { Standard } \\
\text { error }\end{array}$} \\
\hline & Before & After & \\
\hline MFGM, g/g of cream & $0.028^{\mathrm{a}}$ & 0.020 & 0.002 \\
\hline MFGM, g/g of lipid & $0.146^{\mathrm{a}}$ & 0.111 & 0.009 \\
\hline Protein, mg/g of cream & 42.54 & 40.35 & 0.88 \\
\hline Protein, mg/10 mg of MFGM & 3.329 & $4.759^{\mathrm{a}}$ & 0.212 \\
\hline Phospholipid adsorbed, \% & $63.22^{\mathrm{a}}$ & 47.51 & 5.18 \\
\hline Phosphodiesterase, $\mu M / \mathrm{mg}$ of protein per min & $48.19^{\mathrm{a}}$ & 33.69 & 4.67 \\
\hline
\end{tabular}

cantly $(P<0.05)$ greater activity, and by percentage phospholipid adsorbed being significantly $(P<0.05)$ higher in these creams. Creams homogenized before pasteurization contained more nondenatured native MFGM available for emulsification upon pasteurization. The nondenatured native MFGM fragments, having more efficient emulsifying properties, oriented themselves at the milk fat globule interface to a greater extent when compared with denatured MFGM (Corredig and Dalgleish, 1997, 1998). This resulted in less surface area being available for casein and whey proteins and more native MFGM being present at the milk fat interface of creams homogenized before pasteurization.

Creams that underwent pasteurization before homogenization had a significantly $(P<0.05)$ higher protein load associated with the pMFGM. Pasteurization denatures native MFGM proteins and more serum proteins are needed to cover the larger surface area created by homogenization of pasteurized creams. In addition, there was probably less secondary layer formation around the processed milk fat globule. This could explain the increased content of pMFGM found in creams pasteurized before homogenization. Lee and Sherbon (2002) found that milk homogenized before pasteurization contained significantly more casein proteins in the membrane, thereby increasing the protein content of the pMFGM by about 3.5-fold (with adsorbed caseins being the major constituents). When the homogenized milk was heated $\left(80^{\circ} \mathrm{C}\right)$, deposition of whey proteins, especially $\beta$-lactoglobulin, occurred on the membrane surface, resulting in a further increase in total protein of the pMFGM. In contrast, Ye et al. (2002) found that heat treatment of $50^{\circ} \mathrm{C}$ for $10 \mathrm{~min}$ resulted in the loss of $\sim 50 \%$ of total protein from the native MFGM of heated washed cream.

Changes in pMFGM composition due to interaction of cream formulation and homogenization sequence are described in Table 4. Natural cream homogenized before pasteurization contained significantly $(P<0.05)$ more MFGM material than natural cream or buttermilk/aqueous phase formulations homogenized after pasteurization. However, higher $(P<0.05)$ protein levels were found in the natural cream and the buttermilk/ aqueous phase formulations when they were homogenized after pasteurization. Emulsifying properties of native MFGM decrease with increased heat treatment due to denaturation, and denatured native MFGM fragments do not adsorb as well as nondenatured MFGM fragments (Corredig and Dalgleish, 1998). Consequently, casein and whey proteins were unable to form complexes with the denatured milk fat globule proteins and less milk fat surface material was found in the lipid. Milk fat globule membrane content of the skim milk formulated creams was not influenced by homogenization sequence. Because skim milk uses casein and whey proteins as the primary emulsifying agents, minimal emulsifying properties are contributed by native MFGM.

Natural cream homogenized after pasteurization had less $(P<0.05)$ available phospholipid associated with the MFGM than natural cream homogenized first or the skim milk formulations homogenized before or after pasteurization. Creams formulated with buttermilk and aqueous phase contained more native MFGM fragments for potential incorporation into the resulting MFGM, and percentages of phospholipid adsorbed were lower in creams formulated with these components. Because creams formulated with skim milk mainly rely on casein and whey proteins as emulsifying agents, the percentage phospholipid adsorbed is relatively high because there was little native MFGM present initially.

\section{Processing Effects on Physical Properties of Natural and Reformulated Creams}

Creaming stability. Milk is properly homogenized if, after $48 \mathrm{~h}$ of storage at $4.4^{\circ} \mathrm{C}$, no visible cream separa- 
Table 4. Influence of formulation/homogenization sequence interaction on processed milk fat globule membrane (MFGM) composition.

\begin{tabular}{lllll}
\hline Cream formulation & $\begin{array}{l}\text { Homogenization } \\
\text { sequence }^{1}\end{array}$ & $\begin{array}{l}\text { MFGM } \\
\text { (g/g of lipid })\end{array}$ & $\begin{array}{l}\text { Protein } \\
\text { (mg/10 mg } \\
\text { of MFGM) }\end{array}$ & $\begin{array}{l}\text { Phospholipid } \\
\text { adsorbed (\%) }\end{array}$ \\
\hline Natural cream & Before & $0.178^{\mathrm{b}}$ & $3.90^{\mathrm{a}}$ & $64.47^{\mathrm{b}}$ \\
Natural cream & After & $0.099^{\mathrm{a}}$ & $5.87^{\mathrm{b}}$ & $27.23^{\mathrm{a}}$ \\
$20 \%$ lmbo $/ 80 \%$ skim milk & Before & $0.120^{\mathrm{ab}}$ & $2.48^{\mathrm{a}}$ & $71.99^{\mathrm{b}}$ \\
$20 \%$ lmbo/80\% skim milk & After & $0.139^{\mathrm{ab}}$ & $3.01^{\mathrm{a}}$ & $76.18^{\mathrm{b}}$ \\
$20 \%$ lmbo/70\% buttermilk/10\% AP $\mathrm{AP}^{3}$ & Before & $0.140^{\mathrm{ab}}$ & $3.58^{\mathrm{a}}$ & $53.20^{\mathrm{ab}}$ \\
$20 \%$ lmbo/70\% buttermilk/10\% AP & After & $0.095^{\mathrm{a}}$ & $5.40^{\mathrm{b}}$ & $39.13^{\mathrm{ab}}$ \\
Standard error & & 0.016 & 0.37 & 8.98 \\
\hline
\end{tabular}

${ }^{\mathrm{a}, \mathrm{b}}$ Different letters within a column are significantly different $(P<0.05)$ based on means from 3 replications.

${ }^{1}$ Two-stage homogenization performed before or after pasteurization. First stage $=13.4 \mathrm{MPa}$; second stage $=3.4 \mathrm{MPa}$.

${ }^{2}$ lmbo = Low-melt butteroil.

${ }^{3} \mathrm{AP}=$ Butter-derived aqueous phase, commercially obtained from Grassland Dairy Products, Inc., Greenwood, WI.

tion occurs within the milk. Milk fat typically rises to the top of an emulsion with increased storage time.

Changes in emulsion stability were minimal throughout the first week of storage. After $7 \mathrm{~d}$ of storage, however, significant $(P<0.05)$ differences in creaming stability were noted for both natural and reformulated creams (data not shown). Regardless of processing conditions, skim milk formulations displayed a significant $(P<0.05)$ decrease in emulsion stability after $7 \mathrm{~d}$ of storage. After $9 \mathrm{~d}$ of storage, natural cream and buttermilk/aqueous phase formulated creams decreased significantly $(P<0.05)$ in creaming stability. Therefore, emulsion stability was similar for natural creams and buttermilk/aqueous phase formulations whereas skim milk formulations were less stable. The skim milk formulated creams had very little native MFGM and relied on casein and whey proteins as emulsifying material (Elling et al., 1996; Scott et al., 2003a).

High temperature, short time-pasteurized natural and reformulated creams were more stable to creaming than UHT-pasteurized natural and reformulated creams. Ultra-high temperature-pasteurized natural and reformulated creams became significantly $(P<$ 0.05 ) less stable after $7 \mathrm{~d}$ of storage, whereas HTSTpasteurized natural and reformulated creams became significantly $(P<0.05)$ less stable after $9 \mathrm{~d}$ of storage. Smith et al. (2000) found that UHT-pasteurized whipping cream was more predisposed to creaming than HTST-pasteurized creams, possibly due to more deterioration of the proteins in the serum phase of the UHT creams.

Viscosity. Apparent viscosity was monitored over 2 wk of storage $\left(4^{\circ} \mathrm{C}\right)$ to determine influence of pasteurization temperature and homogenization sequence on the flow characteristics of natural and reformulated creams. Time of storage did not influence viscosity of creams; therefore, only apparent viscosity (hysteresis) curves from d 1 of storage are reported. Scott et al. ( $2003 \mathrm{~b}$ ) found viscosity to be consistent in $20 \%$ milk fat creams stored for $2 \mathrm{wk}\left(3.3^{\circ} \mathrm{C}\right)$.

Creams in this study displayed non-Newtonian behavior at shear rates between 692 and $2496 \mathrm{~s}^{-1}$ (Figure 1). Non-Newtonian fluid flow is characterized by a decrease in apparent viscosity due to an increase in shear rate, or by an increase in viscosity due to a decrease in shear rate (Sherbon, 1988). This is observed when the hysteresis curve fails. Higher apparent viscosity values were associated with failing curves. This can be attributed to break down of colloidal aggregate particles as increasing shear was applied during the first stage of viscosity measurements (Fox and McSweeney, 1998).

Pasteurization temperature had a significant $(P<$ 0.05 ) effect on apparent viscosity of natural and reformulated creams. At all shear rates monitored, UHTpasteurized cream formulations were significantly $(P<$ 0.05) higher in viscosity than HTST-pasteurized creams (Table 5). Corredig and Dalgleish (1996) found UHT-pasteurized cream had more $\beta$-lactoglobulin in the pMFGM compared with HTST-pasteurized cream. The temperatures used for UHT pasteurization cause $\beta$-lactoglobulin to associate with materials on the milk fat surface. Because the structure of $\beta$-lactoglobulin is more defined than casein protein structure, milk fat floccules may be present, resulting in the greater resistance to shear observed in UHT-pasteurized cream (Dalgleish, 1990).

Interaction of pasteurization process with cream formulation had a significant $(P<0.05)$ effect on the apparent viscosity of natural and reformulated creams (Figure 1). Ultra-high temperature pasteurized creams formulated with buttermilk and aqueous phase were generally more viscous than other UHT-pasteurized 


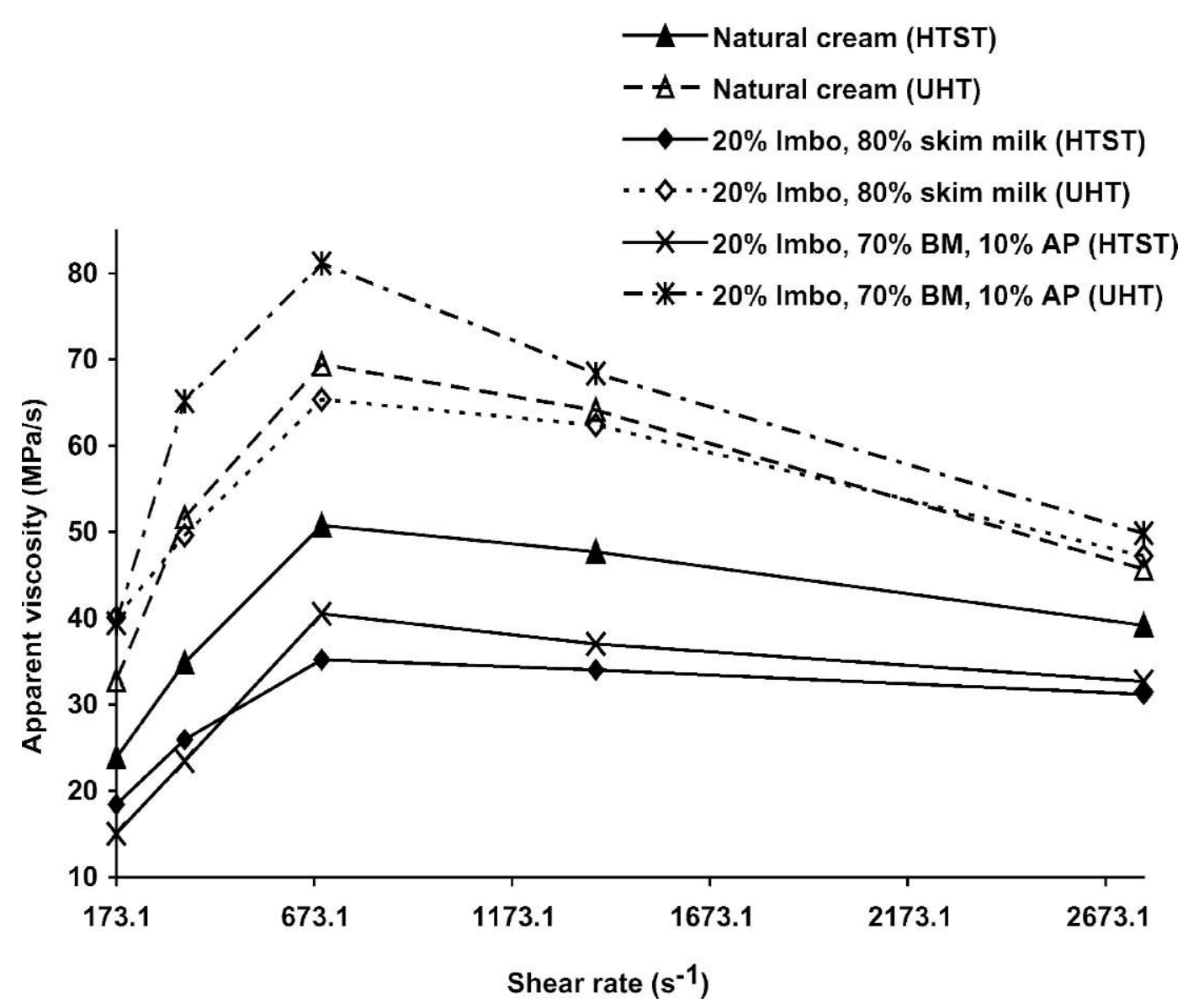

Figure 1. Effect of pasteurization process (UHT or HTST) on apparent viscosity of 20\%-milk fat natural creams and creams formulated with low-melt butteroil (lmbo) and skim milk, or buttermilk (BM) and aqueous phase (AP) on d 1 of storage at $7^{\circ} \mathrm{C}$.

cream formulations. At a shear rate of $692 \mathrm{~s}^{-1}$, UHTpasteurized cream formulated with buttermilk and aqueous phase was significantly $(P<0.05)$ higher in

Table 5. Effect of pasteurization process on apparent viscosity $(\mathrm{MPa} /$ s) of natural and reformulated creams.

\begin{tabular}{llll}
\hline \multirow{2}{*}{$\begin{array}{l}\text { Shear rate } \\
\left(\mathrm{s}^{-1}\right)\end{array}$} & \multicolumn{2}{c}{ Pasteurization type } & \\
\cline { 2 - 3 } & HTST $^{1}$ & UHT $^{2}$ & $\begin{array}{l}\text { Standard } \\
\text { error }\end{array}$ \\
\hline 173.12 & 19.09 & $37.41^{\mathrm{a}}$ & 1.94 \\
346.24 & 28.06 & $55.46^{\mathrm{a}}$ & 1.87 \\
692.48 & 42.17 & $71.95^{\mathrm{a}}$ & 1.77 \\
1394.98 & 39.58 & $64.95^{\mathrm{a}}$ & 1.41 \\
2769.92 & 34.35 & $47.57^{\mathrm{a}}$ & 0.72 \\
1384.92 & 36.85 & $57.63^{\mathrm{a}}$ & 0.99 \\
692.48 & 38.26 & $62.16^{\mathrm{a}}$ & 1.27 \\
346.24 & 23.06 & $42.77^{\mathrm{a}}$ & 1.10 \\
173.12 & 14.77 & $26.78^{\mathrm{a}}$ & 1.16 \\
\hline
\end{tabular}

${ }^{a}$ Viscosity is significantly greater than the corresponding value taken at the same shear rate but processed at a different pasteurization temperature $(P<0.05)$; based on means of 3 replications.

${ }^{1} \mathrm{HTST}=77^{\circ} \mathrm{C}$ for $15 \mathrm{~s}$.

${ }^{2} \mathrm{UHT}=148^{\circ} \mathrm{C}$ for $2 \mathrm{~s}$. viscosity than the other UHT-pasteurized cream formulations. Processing of the formulation components could have oriented native MFGM into positions more susceptible to interaction with $\beta$-lactoglobulin. Lee and Sherbon (2002) did not find an increase in viscosity of whole milk with heating $\left(80^{\circ} \mathrm{C}\right)$ or homogenization. However, combined treatments of heating and homogenization, regardless of processing order, resulted in a significant increase in the viscosity of milk when compared with the viscosity of raw milk, suggesting that the stability of an emulsion improved with increased viscosity.

At shear rates where creams displayed nonNewtonian flow, HTST-pasteurized natural cream was significantly $(P<0.05)$ higher in viscosity than HTST-pasteurized cream formulated with skim milk (Figure 1). Previous studies have determined that milk possessing higher apparent viscosity is more stable to creaming (Wibley, 1992; Lee and Sherbon, 2002). However, this research found that HTST-pasteurized creams were more stable yet less viscous than UHT pasteurized creams. 
High temperature, short time-pasteurized natural cream was significantly $(P<0.05)$ more viscous than cream formulated with buttermilk and aqueous phase at most rising curve shear rates (Figure 1). These results agree with the findings of Scott et al. (2003b) who emulsified low-melt butteroil in $20 \%$-milk fat creams using skim milk or buttermilk and butter-derived aqueous phase. Elling and Duncan (1996) however, used a reduced cholesterol butteroil with different melting properties than the butteroil used in this study and found natural cream to be less viscous than creams formulated with skim milk or buttermilk and aqueous phase. The variation in properties of the butteroils may have contributed to differences in apparent viscosity values of cream formulations in these studies.

Feathering. The multiple heating steps (i.e., pasteurization of components and creams) applied to the creams in this study during processing increased sensitivity to denaturation when the formulations were added to hot $\left(85^{\circ} \mathrm{C}\right)$ and cold $\left(4^{\circ} \mathrm{C}\right)$ buffer solutions. Creams were examined for feathering at cold temperatures to mimic storage conditions. Homogenization sequence and pasteurization type did not significantly $(P$ $>0.05$ ) increase susceptibility of natural and reformulated creams to feathering at either temperature investigated. These results agree with those of Geyer and Kessler (1989) who found UHT- and HTST-pasteurized $12 \%$ milk fat creams displayed similar degrees of feathering.

Feathering scores of 0 to -2 were issued for most creams, indicating that creams were moderately stable to slightly unstable at a $\mathrm{pH}$ range of 5.00 to 5.20 . Scott et al. (2003b) and Elling and Duncan (1996) found that natural and reformulated 20\%-milk fat creams feathered in a $\mathrm{pH}$ range of 4.70 to 5.09 . Variation in feathering values between studies probably occurred because of differences in the processing of the creams.

Microbiological and sensory analyses. A high quality cream has a clean, slightly sweet, slightly cooked flavor and a texture that is smooth, free of fat plugs and lumps (Jensen and Poulsen, 1992). The presence of off-flavors and texture defects may be indicative of various factors such as microbial growth or enzymatic activity, processing, storage conditions, or low emulsion stability.

Enumeration of aerobic bacteria, psychrotrophs, and coliforms was conducted to insure that creams were pasteurized properly and were microbiologically safe for consumption by sensory panelists. Efficient pasteurization and proper refrigeration resulted in low $(<25$ $\mathrm{cfu} / \mathrm{mL}$ ) coliform and psychrotrophic bacteria counts for all creams on d 0,6 , and 12 of storage. As time of storage progressed, aerobic bacteria counts increased in the HTST-pasteurized creams. By d 12, counts averaged
$182 \pm 51 \mathrm{cfu} / \mathrm{mL}$. Ultra-high temperature pasteurized creams remained low $(<25 \mathrm{cfu} / \mathrm{mL})$ in aerobic bacteria numbers throughout storage.

The majority of the creams in this study were observed to have a "cooked" flavor. This observation did not result in creams being deemed "Out" of specification. As length of storage increased, an increasing number of cream formulations were evaluated as "Out" of specification, primarily due to textural defects. Because the majority of the creams demonstrated separation around $\mathrm{d} 7$ of storage, only $\mathrm{d}-1$ results for cream sensory evaluation will be discussed.

All HTST-pasteurized cream formulations were deemed "In" specification (60\% acceptance rate) regardless of homogenization sequence. Of the creams subjected to UHT pasteurization, only the natural cream and the buttermilk/aqueous phase cream homogenized after pasteurization were considered to be "In" specification. None of the UHT-pasteurized skim milk formulations was considered acceptable. Scott et al. (2003b) found skim milk/low-melt butteroil cream formulations (HTST-pasteurized) to be unacceptable in sensory quality. Panelists noted oxidized and flat off-flavors associated with this formulation that were attributed to lowmelt butteroil being more susceptible to oxidation and to skim milk having few characteristics capable of masking the oxidized flavor.

\section{CONCLUSIONS}

Effects of HTST or UHT pasteurization, and homogenization sequence on the physicochemical properties of natural and reformulated creams (manufactured with a low-melt fractionated butteroil and milk-derived components) were examined. Both pasteurization temperature and homogenization sequence affected the physicochemical properties of the cream formulations.

Ultra-high-temperature-pasteurized natural and reformulated creams were significantly more viscous than HTST-pasteurized natural and reformulated creams, indicating that viscosity was highly influenced by thermal process. Homogenization sequence affected the type and amount of surface-active agents at the milk fat interface. Creams homogenized after pasteurization contained more protein and less phospholipid oriented at the milk fat surface. Creams formulated with buttermilk and butter-derived aqueous phase most closely mimicked the physicochemical properties of natural cream.

\section{ACKNOWLEDGMENTS}

The authors would like to acknowledge Dairy Management Incorporated for funding this project. In addi- 
tion, appreciation is extended to Grassland Dairy Products Inc., for contribution of commercially processed components and to Wisconsin Center for Dairy Research for the fractionated butteroils. This material is based on work supported by the Cooperative State Research, Education and Extension Service, U.S. Department of Agriculture, under Project No. VA-135552. Any opinions, findings, conclusions, or recommendations expressed in this publication are those of the authors and do not necessarily reflect the view of the USDA.

\section{REFERENCES}

Anderson, M., B. E. Brooker, T. E. Cawston, and G. C. Cheeseman. 1977. Changes during storage in stability and composition of ultra-heat-treated aseptically packed cream of $18 \%$ fat content. J. Dairy Res. 44:111-123.

Atherton, H. V., and J. A. Newlander. 1977. Chemistry and Testing of Dairy Products. Avi Publishing Company, Inc., Westport, CT.

Bligh, E. G., and W. J. Dyer. 1959. A rapid method for total lipid extraction and purification. Can. J. Biochem. Physiol. 37:911-917.

Brown, A. W., M. P. Lok, and J. Elovson. 1976. Improved method for the isolation of rat liver plasma membrane. Biochim. Biophys. Acta 426:418-432.

Corredig, M., and D. G. Dalgleish. 1996. Effect of different heat treatments on the strong binding interactions between whey proteins and milk fat globules in whole milk. J. Dairy Res. 63:441-449.

Corredig, M., and D. G. Dalgleish. 1997. Isolates from industrial buttermilk: Emulsifying properties of materials derived from the milk fat globule membrane. J. Agric. Food Chem. 45:4595-4600.

Corredig, M., and D. G. Dalgleish. 1998. Effect of heating of cream on the properties of milk fat globule membrane isolates. J. Agric. Food Chem. 46:2533-2540.

Dalgleish, D. G. 1990. Denaturation and aggregation of serum proteins and caseins in heated milk. J. Agric. Food Chem. 38:1995-1999.

Dalgleish, D. G., and J. M. Banks. 1991. The formation of complexes between serum proteins and fat globules during heating of whole milk. Mischwissenschaft 46:75-78.

Dalgleish, D. G., and S. K. Sharma. 1993. Interactions between milkfat and milk proteins-The effect of heat on the nature of the complexes. In Protein and Fat Globule Modifications by Heat Treatment, Homogenization and Other Technologies for High Quality Dairy Products, IDF Special Issue 9303. International Dairy Federation, Brussels, Belgium.

Elling, J. L., and S. E. Duncan. 1996. Physical properties of $20 \%$ milk fat reformulated creams manufactured from cholesterol-reduced butteroil. J. Food Sci. 61:375-378.

Elling, J. L., S. E. Duncan, T. W. Keenan, W. N. Eigel, and J. Boling. 1996. Composition of $20 \%$ milk fat reformulated cream manufactured from reduced cholesterol butteroil. J. Food Sci. 61:48-53.
Folch, J., M. Lees, and G. H. S. Stanley. 1957. A simple method for the isolation and purification of total lipids from animal tissues. J. Biol. Chem. 226:497-592.

Fox, P. F., and P. L. H. McSweeney. 1998. Dairy Chemistry and Biochemistry. 1st ed. Blackie Academic Professional, London, UK.

Geyer, S., and H. G. Kessler. 1989. Influence of individual milk constituents on coffee cream feathering in hot coffee. Milchwissenschaft 44:284-288.

Iametti, S., L. Versuraro, S. Tragna, R. Giangiacomo, and F. Bonomi. 1997. Surface properties of the fat globule in treated creams. Int. Dairy J. 7:375-380.

Jensen, G. K., and H. H. Poulsen. 1992. Sensory Aspects. In Pasteurization of Cream. Bulletin Int. Dairy Fed. \#271, International Dairy Federation, Brussels, Belgium.

Kaylegian, K. E. 1998. Technical Data Sheet of Experimental Milkfat Fractions. Wisconsin Center for Dairy Research, University of Wisconsin, Madison.

Lee, S. J., and J. W. Sherbon. 2002. Chemical changes in bovine milk fat globule membrane caused by heat treatment and homogenization of whole milk. J. Dairy Res. 69:555-567.

Marshall, R. T. 1993. Standard Methods for the Examination of Dairy Products. 16th ed. Am. Public Health Assoc., Inc., Washington, DC.

Munoz, A. M., G. V. Civille, and B. T. Carr. 1992. Sensory Evaluation in Quality Control. Van Nostrand Reinhold, New York, NY.

Rouser, G., A. N. Siakotos, and S. Fleischer. 1966. Quantitative analysis of phospholipids by thin-layer chromatography and phosphorous analysis of spots. Lipids 1:85-86.

SAS Institute. 1985. SAS User's Guide. Statistics, Version 5.0 ed. SAS Institute, Inc., Cary, NC.

Scott, L. L., S. E. Duncan, S. S. Sumner, K. M. Waterman, and K. E. Kaylegian. 2003a. Influence of emulsifying component composition on creams formulated with fractionated milkfat. J. Agric. Food Chem. 51:5933-5940.

Scott, L. L., S. E. Duncan, S. S. Sumner, and K. M. Waterman. 2003b. Physical properties of cream reformulated with fractionated milk fat and milk-derived components. J. Dairy Sci. 86:3395-3404.

Segall, K. I., and H. D. Goff. 2002. Secondary adsorption of milk proteins from the continuous phase to the oil-water interface in dairy emulsions. Int. Dairy J. 12:889-897.

Sherbon, J. W. 1988. Physical Properties of Milk. Pages 409-460 in Fundamentals of Dairy Chemistry. Ch. 10. N. P. Wong, ed. Van Nostrand Reinhold, New York, NY.

Smith, A. K., Y. Kakuda, and H. D. Goff. 2000. Changes in protein and fat structure in whipped cream caused by heat treatment and addition of stabilizer to the cream. Food Res. Int. 33:697-706.

Walstra, P. 1975. Effect of homogenization on the fat globule size distribution in milk. Neth. Milk Dairy J. 29:279-285.

Walstra, P., and H. Oortwijn. 1982. The membranes of recombined fat globules. Neth. Milk Dairy J. 36:103-113.

Wibley, A. 1992. Homogenization. J. Soc. Dairy Technol. 45:31-32.

Ye, A., H. Singh, M. W. Taylor, and S. Anema. 2002. Characterization of protein components of natural and heat-treated milk fat globule membranes. Int. Dairy J. 12:393-402. 